\title{
Assessment of Knowledge Attitude Perception and Practice of Health Insurance Scheme among Community Pharmacies in Lagos State
}

\author{
Article by Ukamaka Gladys Okafor \\ Ph.D in Public Health, Texila American University, Nigeria \\ E-mail: chinaemelum9291@yahoo.com
}

\begin{abstract}
Introduction: In most developing countries, Nigeria in particular, there is little equity and a clear lack of universal coverage of health care. Majority of the health seeking people first visit the community pharmacies when they are ill, before visiting the hospitals, yet a large percentage of Community Pharmacies are not registered with the National Health Insurance Scheme. The objective of the study was to assess the Knowledge, Attitude, Perception and Practice of the Health Insurance Scheme among Community Pharmacists in Lagos State, with the hope that it would serve as a baseline study towards improving Community Pharmacists' involvement in the implementation of the Health Insurance Scheme.

Method: A cross-sectional descriptive study was carried out on 200 Community Pharmacists in Lagos State using a multi-staged stratified random sampling method and structured questionnaire. Analysis was done with Statistical Package for Social Sciences (SPSS) version 14.0 to obtain the frequencies, percentages and descriptive statistical results.

Result: Majority of the respondents were females (60\%), in the age range of 41years and above (47\%), without additional qualifications (70\%), and $73 \%$ with more than 16 years post qualification experience. More than $80 \%$ had poor knowledge of the major guidelines and activities in Health Insurance Scheme while $86 \%$ were neither registered nor participating. Lack of integration among health care providers, lack of prescription from hospitals, need for cumbersome data, inadequate funding and training, lack of capitation for pharmacists were seen as the major hindrances to their participation.

Conclusion: The study revealed poor knowledge, attitude, perception and practice of the Health Insurance Scheme, among Community Pharmacists. Adequate training of community pharmacists and funding of the scheme, modifying the payment system to capitation as well as improving coordination, integration and standard of operation of the Health Insurance Scheme will improve their involvement.
\end{abstract}

Keywords: Community Pharmacists, Knowledge, Attitude, Perception, Practice, Health Insurance

\section{Introduction}

\section{Health insurance system in nigeria}

In most developing countries, Nigeria in particular, there is little equity and a clear lack of universal coverage of health care. Access to healthcare is severely limited in Nigeria (Otuyemi, 2001). Inabilities of the consumers to pay for the services as well as inequitable healthcare provision have been identified among other factors that impose the limitation (Sanusi et al., 2009). Financing of Public Health services in Nigeria has been through Government subvention funded mainly from earnings from petroleum exports and user fees from patients. Decline in funding for healthcare commenced after the mid 1980's following a drastic reduction in revenue from oil exports, mounting external debts burden, structural adjustment programme and rapid population growth rate. The result as in most other developing countries was a rapid decline in the quality and effectiveness of publicly provided healthcare service. As a way out, the Government of Nigeria launched a National Health Insurance Scheme (NHIS) in June 2005 (Ononokpono, 2008). It is the opinion of Nigerian 
Government that the NHIS will solve the problem of inequity in the provision of healthcare services and help to improve accessibility to healthcare (Ibiwoye et al., 2007).

\section{Basic operations of the NHIS}

The employer and employees register with the Scheme. Thereafter, the employee enrolls him/herself with an NHIS approved Health Maintenance Organization (HMO), who will thereafter provide the employees/contributors with a list of NHIS approved Healthcare providers (public and private). The employee registers him/herself and dependent(s) with the provider of his/her choice. Contributions are earning-related and currently stand at $15 \%$ of basic salary. The employer pays $10 \%$ while the employee pays 5\% of basic salary to enjoy healthcare benefit. As at December 2015, only the employer's contribution was being implemented. The contribution made by/for an insured person entitles him/her, a spouse and 4 biological children under the age of 18 to health benefits as contained in NHIS health benefits package. Additional contributions are required for extra dependents (National Health Insurance Scheme, 2005) An enrollee reserves the right to change his/her primary healthcare provider after a minimum of 6 months, if he/she is not satisfied with the services being given. The HMO will make payment for services rendered to an enrollee to the healthcare provider an enrollee may however be asked to make a small co-payment (where applicable) at the point of service (NHIS, 2005).

\section{Stakeholders in NHIS}

- Health Maintenance Organizations

- Health Care Providers: these healthcare providers can be primary (medical doctors/prescribers), secondary (pharmacists) or tertiary.

- Financial Institutions: these include banks, insurance companies and insurance brokers.

- Government and other employees of labor.

- Enrollees/ beneficiaries.

In 2015, the Lagos State government signed the Health Management Agency Bill into law which includes the Community Based Health Insurance Scheme and the community pharmacists, among other relevant stakeholders have been invited to make submissions towards a hitch-free implementation phase. Despite the grey areas, the Association of Community Pharmacists of Nigeria in collaboration with the Health Care Provider Association of Nigeria encourages all Community Pharmacists the insurance scheme has a lot of benefits for all, including the community pharmacists (Oyebade,2016).

\section{Health care providers}

There cannot be healthcare without the healthcare providers who influence both the quality and cost of healthcare through their influences on the nature and quality of treatment required (Onuekwusi et al, 1998). The successful implementation of the Health Insurance Scheme to a large extent depends on the knowledge, attitude, perception and practice of healthcare providers. Pharmacists are certified medicine experts and are key personnels among the healthcare providers. This is because Pharmacists are custodians of medicines (drugs in form of tablet, suppositories and intravenous fluids) as well as surgical materials (plasters, bandages, sutures and other dressing materials) that are required by almost all patients for treatment or management of diseases, wound or infections after proper diagnosis.

Within the community, majority of the health seeking people first visit the community pharmacies when they are ill, before visiting the hospitals, yet a large percentage of Community Pharmacies are not registered with the National Health Insurance Scheme, despite essential drugs from NHIS accredited pharmacy providers and provision of pharmaceutical care by the Pharmacist being a major benefit package of the scheme. 
Assessment of the Scheme after four years of operation reveals less than 3\% coverage of the Nigeria population, basically employees of the federal government, armed forces, the police and other uniformed services, state governments and a handful of private sector organizations. This is due to lack of public awareness and people's acceptance of NHIS (Ibong Ukpong, 2009). The NHIS will therefore need to stimulate acceptance of the formal sector and growth of its informal sector programme; the Community-Based Social Health Insurance Programme (CBSHIP) in order to guarantee coverage for the envisaged 70 per cent of the population that belongs to the informal sector. This would optimally engage healthcare providers in private sector. The Objectives of the study therefore are:

- To assess the Knowledge, Attitude, Perception and Practice of the Health Insurance Scheme among Community Pharmacists in Lagos State.

- To serve as a baseline study towards improving Community Pharmacists' involvement in the implementation of the Health Insurance Scheme.

\section{Limitations}

- Inability of the Research Assistants to reach all the randomly selected pharmacies

- The time allocated for the study was too short to retrieve all the questionnaires, hence the high attrition rate

\section{Methods}

\section{Study area}

Lagos State, the economic nerve centre of Nigeria, is located in the southwestern geopolitical zone of the country. The State is essentially a Yoruba-speaking environment; a social-cultural melting pot attracting both Nigerians and foreigners (History of Lagos State, 2014).

Lagos State consists of three senatorial districts; Lagos Central, Lagos East and Lagos West. (History of Lagos State, 2014). According to the Pharmacists Council of Nigeria Register of Pharmacists and Pharmaceutical premises, there were 1227 pharmacists working in the private sector, 768of whom worked in community pharmacies in Lagos State in December 2014.

\section{Sampling technique}

The 768 community pharmacists constitute the sample frame from which a sample size of 257 community pharmacists was generated using Raosoft's formula for sample size determination; this sample frame is the population that run retail community pharmacies, are registered with the Pharmacists Council of Nigeria and Association of Community Pharmacists of Nigeria, and interface directly with the patients.

Multi-staged stratified random sampling method was employed in the selection of 257participants. Pre-tested semi-structured questionnaires were administered to the superintendent pharmacists or the pharmacists with the longest experience in the selected community pharmacies during the working hours. Items included in the questionnaire covered different parameters such as Ability to list the types of Insurance scheme, Objectives, Key Stakeholders, Payment System, assessment of the Knowledge, Attitude, Perception and Practice of the Health Insurance Scheme among Community Pharmacists in Lagos State.

\section{Data analysis and interpretation}

The retrieved copies of the questionnaire were entered into the Microsoft excel computer package and analyzed with Statistical Package for Social Sciences (SPSS) version 14.0 to obtain the frequencies, percentages and descriptive statistical results. 
Texila International Journal of Public Health

Volume 4, Issue 4, Dec 2016

\section{Results}

Out of the 257 total numbers of questionnaires administered, only 100 were retrieved and used for the study.

\section{Biodata}

Table 1.1

\begin{tabular}{|c|c|c|c|c|c|c|c|}
\hline \multicolumn{8}{|c|}{ Sex * Age Range Cross-Tabulation } \\
\hline & & \multicolumn{5}{|c|}{ Age Range } & \multirow[t]{2}{*}{ Total } \\
\hline & & $<26$ & $26-30$ & $31-35$ & $36-40$ & 41 and above & \\
\hline \multirow[t]{2}{*}{ Sex } & Male & 0 & 6 & 8 & 8 & 18 & 40 \\
\hline & Female & 1 & 9 & 10 & 11 & 29 & 60 \\
\hline \multicolumn{2}{|c|}{ Total } & 1 & 15 & 18 & 19 & 47 & 100 \\
\hline
\end{tabular}

Table 1.1 is a cross-tabulation of age/sex demographic information which shows that $1 \%$ of respondents of age less than 26years is a female, out of the $15 \%$ of age class $26-30,6 \%$ are male and $9 \%$ are females; $8 \%$ are males and $10 \%$ females make up $18 \%$ of the $31-35$ age range, $8 \%$ are males and $11 \%$ females make up $19 \%$ of the $36-40$ age range while $18 \%$ are males and $29 \%$ females make up $47 \%$ of the 41 years and above age range.

Table 1.2

\begin{tabular}{|l|l|l|l|l|l|}
\hline \multicolumn{6}{|l|}{ Years of Work Experience As Community Pharmacist } \\
\hline \multicolumn{1}{|c|}{} & Frequency & Percent & Valid Percent & $\begin{array}{l}\text { Cumulative } \\
\text { Percent }\end{array}$ \\
\hline \multirow{4}{*}{ Valid } & $1-5$ & 2 & 2.0 & 2.0 & 2.0 \\
\cline { 2 - 6 } & $6-10$ & 5 & 5.0 & 5.0 & 7.0 \\
\cline { 2 - 6 } & $11-15$ & 19 & 19.0 & 19.0 & 26.0 \\
\cline { 2 - 6 } & $16-20$ & 25 & 25.0 & 25.0 & 51.0 \\
\cline { 2 - 6 } & 21 and above & 49 & 49.0 & 49.0 & 100.0 \\
\cline { 2 - 6 } & Total & 100 & 100.0 & 100.0 & \\
\hline
\end{tabular}

Table 1.2 shows that work experience ranges (years) 1-5, 6-10, 11-15, 16-20 and 21 years and above have percentage frequency of 2,5,19,25 and 49 respectively.

\section{Assessment of Knowledge}

Table 1.3

\begin{tabular}{|l|l|l|l|l|l|}
\hline \multicolumn{6}{|l|}{ What Are The Health Insurance Scheme in Lagos State? } \\
\hline \multicolumn{2}{|c|}{} & Frequency & Percent & Valid Percent & $\begin{array}{l}\text { Cumulative } \\
\text { Percent }\end{array}$ \\
\hline \multirow{3}{*}{ Valid } & Ability to list & 10 & 10.0 & 10.0 & 10.0 \\
\cline { 2 - 6 } & Inability to list & 90 & 90.0 & 90.0 & 100.0 \\
\cline { 2 - 6 } & Total & 100 & 100.0 & 100.0 & \\
\hline
\end{tabular}

Table 1.3 indicates that $10 \%$ of respondents could list the Health Insurance Scheme in Lagos State while $90 \%$ of the respondents have no knowledge of the Scheme. 
Table 1.4

\begin{tabular}{|c|c|c|c|c|c|}
\hline \multicolumn{6}{|c|}{$\begin{array}{l}\text { At What Level Does The Community Pharmacist Operate in The Health Insurance } \\
\text { Scheme? }\end{array}$} \\
\hline & & Frequency & Percent & $\begin{array}{l}\text { Valid } \\
\text { Percent }\end{array}$ & $\begin{array}{l}\text { Cumulativ } \\
\text { e Percent }\end{array}$ \\
\hline \multirow[t]{4}{*}{ Valid } & Primary Health Provider & 54 & 54.0 & 54.0 & 54.0 \\
\hline & Secondary Health Provider & 6 & 6.0 & 6.0 & 60.0 \\
\hline & Tertiary Health Provider & 40 & 40.0 & 40.0 & 100.0 \\
\hline & Total & 100 & 100.0 & 100.0 & \\
\hline
\end{tabular}

Table 1.4 indicates that only 6\% of respondents have knowledge that Community Pharmacists operate as Secondary Health Provider.

Table 1.5

\begin{tabular}{|l|l|l|l|l|l|}
\hline \multicolumn{6}{|l|}{ Enrolment in The Health Insurance Scheme } \\
\hline \multicolumn{2}{|c|}{} & Frequency & Percent & Valid Percent & $\begin{array}{l}\text { Cumulativ } \\
\text { e Percent }\end{array}$ \\
\hline \multirow{4}{*}{ Valid } & Excellent & 2 & 2.0 & 2.0 & 2.0 \\
\cline { 2 - 6 } & Above average & 4 & 4.0 & 4.0 & 6.0 \\
\cline { 2 - 6 } & Average & 10 & 10.0 & 10.0 & 16.0 \\
\cline { 2 - 6 } & Below average & 4 & 4.0 & 4.0 & 20.0 \\
\cline { 2 - 6 } & Extremely poor & 80 & 80.0 & 80.0 & 100.0 \\
\cline { 2 - 6 } & Total & 100 & 100.0 & 100.0 & \\
\hline
\end{tabular}

Table 1.5 shows that $2 \%$ of respondents have excellent knowledge on enrollment of Community Pharmacists into the Health Insurance Scheme, 10\% above average while $80 \%$ have extremely poor knowledge.

Table 1.6

\begin{tabular}{|l|l|l|l|l|l|}
\hline \multicolumn{2}{|l|}{ Requirements of Accreditation of Facility } \\
\hline \multicolumn{2}{|c|}{} & Frequency & Percent & Valid Percent & $\begin{array}{l}\text { Cumulative } \\
\text { Percent }\end{array}$ \\
\hline \multirow{7}{*}{ Valid } & Excellent & 1 & 1.0 & 1.0 & 1.0 \\
\cline { 2 - 6 } & Above average & 4 & 4.0 & 4.0 & 5.0 \\
\cline { 2 - 6 } & Average & 2 & 2.0 & 2.0 & 7.0 \\
\cline { 2 - 6 } & Below average & 6 & 6.0 & 6.0 & 13.0 \\
\cline { 2 - 6 } & Extremely poor & 87 & 87.0 & 87.0 & 100.0 \\
\cline { 2 - 6 } & Total & 100 & 100.0 & 100.0 & \\
\hline
\end{tabular}

Table 1.6 indicates $1 \%$ of respondents have excellent knowledge, $4 \%$ above average, $2 \%$ average, $6 \%$ below average while $87 \%$ have extremely poor knowledge on the requirements of accreditation of facility to be registered in the Health Insurance Scheme.

Other areas where the respondents were found to have extremely poor knowledge of the scheme included objectives of the scheme (31\%); forms/types of health insurance scheme (87\%), structure (87\%); key stakeholders (87\%); payment system (72\%); steps for accreditation (82\%); and conditions for renewal of accreditation (84\%). 


\section{Assessment of Perception}

Table 1.7

\begin{tabular}{|l|l|l|l|l|l|}
\hline \multicolumn{6}{|c|}{ Is Your Facility Registered with The Health Insurance Scheme? } \\
\hline \multicolumn{2}{|c|}{} & Frequency & Percent & $\begin{array}{l}\text { Valid } \\
\text { Percent }\end{array}$ & $\begin{array}{l}\text { Cumulativ } \\
\text { e Percent }\end{array}$ \\
\hline \multirow{3}{*}{ Valid } & Yes & 14 & 14.0 & 14.0 & 14.0 \\
\cline { 2 - 6 } & No & 86 & 86.0 & 86.0 & 100.0 \\
\cline { 2 - 6 } & Total & 100 & 100.0 & 100.0 & \\
\hline
\end{tabular}

Table 1.7 indicates $14 \%$ of respondents' facilities are registered with the Health Insurance Scheme while $86 \%$ of the respondents' facilities are not registered.

Table 1.8

\section{Coordination, Integration And Standard of Operation}

\begin{tabular}{|l|l|l|l|l|l|}
\hline \multicolumn{2}{|c|}{} & Frequency & Percent & Valid Percent & $\begin{array}{l}\text { Cumulative } \\
\text { Percent }\end{array}$ \\
\hline \multirow{3}{*}{ Valid } & Strongly Agree & 84 & 84.0 & 84.0 & 84.0 \\
\cline { 2 - 6 } & Agree & 10 & 10.0 & 10.0 & 94.0 \\
\cline { 2 - 6 } & Neutral & 5 & 5.0 & 5.0 & 99.0 \\
\cline { 2 - 6 } & Strongly Disagree & 1 & 1.0 & 1.0 & 100.0 \\
\cline { 2 - 6 } & Total & 100 & 100.0 & 100.0 & \\
\hline
\end{tabular}

Table 1.8 indicates $84 \%$ strongly agree, $10 \%$ agree, $5 \%$ neutral while $1 \%$ of respondents strongly disagree on the coordination, integration and standard of operation of the Health Insurance Scheme.

Other reasons given for non-enrolment with the scheme and factors that affect the scheme include lack of integration among health care providers (90\%); lack of prescriptions from the hospitals (86\%); data integrity (96\%); cumbersome data (91\%); lack of training on data management (93\%); insufficient funds (88\%); lack of capitation (94\%) and non-payment by government hospitals (65\%).

\section{Assessment of Practice of the NHIS}

This section assessed the respondents already participating in the scheme

Table 1.9

\begin{tabular}{|l|l|l|l|l|l|}
\hline \multicolumn{6}{|c|}{ How Many Years Has Your Facility Been Providing Services? } \\
\hline \multirow{3}{*}{} & Frequency & Percent & Valid Percent & $\begin{array}{l}\text { Cumulativ } \\
\text { e Percent }\end{array}$ \\
\hline Valid & $<2$ years & 2 & 2.0 & 2.0 & 2.0 \\
\cline { 2 - 6 } & $2-5$ years & 97 & 97.0 & 97.0 & 99.0 \\
\cline { 2 - 6 } & $6-9$ years & 1 & 1.0 & 1.0 & 100.0 \\
\cline { 2 - 6 } & Total & 100 & 100.0 & 100.0 & \\
\hline
\end{tabular}

Table 1.39 shows that $2 \%$ of respondents have less than 2 years $97 \%$ have $2-5$ years experience while 1\% had 6-9 years of their facilities providing services in the Social Health Insurance Scheme. 
Table 2.0

\begin{tabular}{|c|c|c|c|c|c|}
\hline \multicolumn{6}{|c|}{$\begin{array}{l}\text { Reasons For Acceptance/Non-Acceptance of The Health Insurance Scheme } \\
\text { (Profitability) }\end{array}$} \\
\hline & & Frequency & Percent & Valid Percent & $\begin{array}{l}\text { Cumulative } \\
\text { Percent }\end{array}$ \\
\hline \multirow[t]{6}{*}{ Valid } & Strongly Agree & 2 & 2.0 & 2.0 & 2.0 \\
\hline & Agree & 40 & 40.0 & 40.0 & 42.0 \\
\hline & Neutral & 33 & 33.0 & 33.0 & 75.0 \\
\hline & Disagree & 10 & 10.0 & 10.0 & 85.0 \\
\hline & $\begin{array}{l}\text { Strongly } \\
\text { Disagree }\end{array}$ & 15 & 15.0 & 15.0 & 100.0 \\
\hline & Total & 100 & 100.0 & 100.0 & \\
\hline
\end{tabular}

Table 2.0 shows that $2 \%$ of respondents strongly agree, $40 \%$ agree, $33 \%$ neutral, $10 \%$ disagree while $15 \%$ strongly disagree that profitability of the Scheme are as one of the reasons for acceptance/ non-acceptance of the Health Insurance Scheme.

Table 2.1

\begin{tabular}{|l|l|l|l|l|l|}
\hline \multicolumn{6}{|l|}{ Rate of Satisfaction with The Health Insurance Scheme } \\
\hline \multicolumn{7}{|c|}{} & Frequency & Percent & Valid Percent & $\begin{array}{l}\text { Cumulativ } \\
\text { e Percent }\end{array}$ \\
\hline Valid & Okay & 9 & 9.0 & 9.0 & 9.0 \\
\cline { 2 - 6 } & Dissatisfied & 1 & 1.0 & 1.0 & 10.0 \\
\cline { 2 - 6 } & $\begin{array}{l}\text { Very } \\
\text { dissatisfied }\end{array}$ & 90 & 90.0 & 90.0 & 100.0 \\
\cline { 2 - 6 } & Total & 100 & 100.0 & 100.0 & \\
\hline
\end{tabular}

Table 2.1 shows that $9 \%$ of respondents are okay, $1 \%$ dissatisfied while $90 \%$ were very dissatisfied about the Health Insurance Scheme.

Other reasons reported by the respondents for their low acceptance and satisfaction included payment mode not understood (80\%); payment not adequate (59\%); and number of client not sufficient (96\%).

\section{Assessment of Attitude}

Table 2.3

\begin{tabular}{|l|l|l|l|l|l|}
\hline \multicolumn{6}{|l|}{ Community Pharmacists Not Carried Along in The Scheme } \\
\hline \multicolumn{2}{|c|}{} & Frequency & Percent & Valid Percent & $\begin{array}{l}\text { Cumulative } \\
\text { Percent }\end{array}$ \\
\hline \multirow{3}{*}{ Valid } & Strongly Agree & 82 & 82.0 & 82.0 & 82.0 \\
\cline { 2 - 6 } & Agree & 17 & 17.0 & 17.0 & 99.0 \\
\cline { 2 - 6 } & Neutral & 1 & 1.0 & 1.0 & 100.0 \\
\cline { 2 - 6 } & Total & 100 & 100.0 & 100.0 & \\
\hline
\end{tabular}

Table 2.3 shows that $82 \%$ of respondents strongly agree, $17 \%$ agree while $1 \%$ is neutral that Community Pharmacists not being carried along in the Scheme are one of the factors that affect the Health Insurance Scheme. 
Table 2.5

\begin{tabular}{|c|c|c|c|c|c|}
\hline \multicolumn{6}{|c|}{$\begin{array}{l}\text { Mode of Payment Should Be Changed To Capitation To Encourage } \\
\text { Participation }\end{array}$} \\
\hline & & Frequency & Percent & Valid Percent & $\begin{array}{l}\text { Cumulative } \\
\text { Percent }\end{array}$ \\
\hline \multirow[t]{3}{*}{ Valid } & Strongly Agree & 97 & 97.0 & 97.0 & 97.0 \\
\hline & Agree & 3 & 3.0 & 3.0 & 100.0 \\
\hline & Total & 100 & 100.0 & 100.0 & \\
\hline
\end{tabular}

Table 2.5 shows that $97 \%$ of respondents strongly agree while $3 \%$ agree that the mode of payment for Community Pharmacists on the Health Insurance Scheme should be changed to capitation.

In addition $47 \%$ of the respondents strongly agree that non-challant attitude of the Community Pharmacists are one of the factors that affect the Health Insurance Scheme while 95\% strongly agree that most Community Pharmacists regret registering for the Health Insurance Scheme.

\section{Discussion}

\section{Demography}

Result of this research shows that $60 \%$ of the respondents were females while $40 \%$ were males. Over the last two decades, there has been a gender shift in the pharmacy profession as women have been graduating from schools of pharmacy at a higher rate than men for over 20 years (Stephanie et al,2006).

Also, $47 \%$ of pharmacists in community practice were in the age range of 41years and above, and this is similar to the results from a related study that found that in the American Pharmacists Association, 53\% of Community Pharmacists are in the mean age of 47 years (Schommer et al, 2007).

\section{Assessment of knowledge}

Assessment of knowledge across the parameters showed a very poor knowledge pattern of the Health Insurance Scheme among the Community Pharmacists; only 10\% of respondents could list the Health Insurance Schemes in Lagos State while only 6\% of respondents had knowledge that Community Pharmacists operate as secondary Health Provider. This shows a very poor knowledge on the Health Insurance Scheme among the respondents. A similar study conducted among members of staff of research institutes in Nigeria also revealed very low level of awareness in these institutions (Akintaro et al, 2015).

\section{Assessment of perception}

Assessment of parameters such as lack of prescriptions from the hospitals, lack of capitation, nonpayment by Government institutions and others showed negative perceptions of the Health Insurance Scheme among the Community Pharmacists. Only fourteen percent (14\%) of respondents' facilities were registered with the Health Insurance Scheme This agrees with the study on 'The Impact of National Health Insurance on Community Pharmacists in Western Region of Ghana (Adjei, 2012).

\section{Assessment of practice}

Assessments of parameters such as years of experience in providing social health insurance services, lack of understanding of payment modes, insufficient numbers of registered clients, profitability and level of satisfaction were some of the factors that lead to poor practice of the Health Insurance Scheme among the Community Pharmacists. These are in agreement with the study 'The Evolution of Taiwan's National Health Insurance Scheme' (Jason et al, 2012). 


\section{Assessment of attitude}

Factors such as non-challant attitude of the Community Pharmacists, Community Pharmacists not being carried along, non-capitation mode of payment for Community Pharmacists were the major factors that led to poor attitude among community pharmacists and which discouraged them from participating in the Health Insurance Scheme. This also agrees with the study on 'The Evolution of Taiwan's National Health Insurance Scheme' (Jason et al; 2012)

\section{Conclusion}

This study reveals that there is poor knowledge, attitude, perception and practice of the Health Insurance Scheme, among Community Pharmacists in Lagos State therefore interventions such as training, structured orientation, modifying the payment system to capitation as well as improving coordination, integration and standard of operation of the Health Insurance Scheme will improve the involvement of this set of professionals.

\section{Reference}

[1]. Adjei M.O (2012): The Impact of National Health Insurance on Community Pharmacies: A Case Study of the Western Region of Ghana. Available at http://ir.knust.edu.gh/bitstream/123456789/4338/1/Adjei\%20Moses\%20Amoah.pdf Accessed on August 25, 2016

[2]. Akintaro O.A and Adewoyin 0.0 (2015): Knowledge and Attitude towards National Health Insurance Scheme in Nigerian Research Institutes. Journal of the Open University of Tanzania Vol 20, No 1 (2015). Available on www.ajol.info Accessed on September 15, 2016

[3]. History of Lagos State (2014). Apublication of the Lagos State Government Public Service.

[4]. Ibiwoye A. and Adeleke A.A. (2007): Does National Health Insurance Promotes Access to Quality Healthcare? Evidence from Nigeria. Available at https://www.researchgate.net/publication/266850158 Accessed on August 25, 2016

[5]. Ibiwoye, A and Adeleke A.A. (2007): The Impact of Health Insurance on Healthcare Provision in Developing Countries. Ghana J. Dev. Stud., 4(21): 49 -58. [6].

[6]. Jason C and Christine Y. (2015): The Evolution of Taiwan's National Health Insurance Drug Reimbursement Scheme.

[7]. National Health Insurance Scheme (2005), Operational Guidelines, Nigerian Govt.Pub.Service.

[8]. National Health Insurance Scheme (2005): Standard Treatment Guideline and Referral Protocol for Primary Healthcare Providers, Nigerian Govt. Pub. Service.

[9]. National Health Insurance Scheme (2015): The Blue-Print Review on Community Based Social Health Insurance Scheme, Nigerian Govt. Pub Service

[10]. Onuekwusi N. and Okpala C.O. (1998): Awareness and Perception of the National Health

[11]. Insurance Scheme (NHIS) Among Nigeria Healthcare Professions. Journal of College of Medicine 3(2): 97 - 99. [13].

[12]. Ononokpono E.(2008): NHIS and the Challenges of Healthcare Delivery. http://www.dailytrust.com/content/view/4297/8.

[13]. Otuyemi, O.D. (2001): Orthodontics in Nigeria: Journey So Far and Challenges Ahead. Journal of Orthodontics 28 (1): 90 - 92. [15].

[14]. Oyebade W., (2016): Community pharmacists raise concerns over Lagos health insurance scheme http://www.dailytrust.com.ng/news/business/-nhis-should-be-well-structured-to-facilitate-healthcarereforms/141646.html\#wpMU2b9jBToiKgdi.

[15]. Owumi B., Omorogbe C., Raphael S. (2009): An evaluation of the impacts of the National Health Insurance Scheme on the Employees' Health Status at the University of Ibadan. African Journal of Social Sciences Volume 3 Number 3 (2013) 40-52. Available at http://www.sachajournals.com/user/image/ajss2013wisdom002.pdf Accessed on September 13, 2016 
Texila International Journal of Public Health

Volume 4, Issue 4, Dec 2016

[16]. PCN (2014): A list of Registered Pharmacists and Pharmaceutical Premises in Nigeria; A publication of the Pharmacists Council of Nigeria.

[17]. Raosoft (2014): Sample size calculator. Available at http://www.raosoft.com/samplesize.html. Accessed March 23, 2016.

[18]. Sanusi and Awe A. T. (2009): An Assessment of Awareness Level of National Health Insurance Scheme (NHIS) among Healthcare Consumers in Oyo State, Nigeria. The Medwell Journals 4(2) 143 - 148. [16]

[19]. Sanusi R.A and Awe, A. T. (2009): Perception of National Health Insurance Scheme (NHIS) by Healthcare consumers in Oyo State, Nigeria. Pakistan Journal of Social Sciences. 6(1): 48 - 53.

[20]. Schommer J.C, Brown L.M, Sogol E.M (2007): Career Pathway Evaluation Program 2007 Pharmacist Profile Survey. Available at https://www.ncbi.nlm.nih.gov/pmc/articles/PMC3831405/ Accessed on August 25, 2016

[21]. Stephanie F.G and Cindy D.S (2006): The Impact of Gender Shift on A Profession: Women in Pharmacy, University of Kansas, Forum on Public Policy. Available at https://pharmacy.ku.edu/ Accessed on August 14, 2016

[22]. WHO (1994): The Role of the Pharmacist in the Healthcare System, Essential Medicine and Health Products Information Portal.www.nhis.gov.ng/file/blueprint (2016). 